DOI: https://doi.org/10.34069/AI/2021.42.06.9

How to Cite:

Cherniei, V., Cherniavskyi, S., Dzhuzha, A., \& Babanina, V. (2021). Combating credit fraud: experience of Ukraine and some other European Countries. Amazonia Investiga, 10(42), 93-102. https://doi.org/10.34069/AI/2021.42.06.9

\title{
Combating credit fraud: experience of Ukraine and some other European Countries
}

\section{ПРОТИДІЯ ШАХРАЙСТВУ У СФЕРІ КРЕДИТУВАННЯ: ДОСВІД УКРАЇНИ ТА ДЕЯКИХ ІНШИХ ЄВРОПЕЙСЬКИХ КРАЇН}

\author{
Received: May 5, $2021 \quad$ Accepted: June 12, 2021
}

\author{
Written by: \\ Volodymyr Cherniei ${ }^{39}$ \\ https://orcid.org/0000-0002-0247-263X \\ Serhii Cherniavskyi ${ }^{40}$ \\ https://orcid.org/0000-0002-2711-3828 \\ Alexander Dzhuzha ${ }^{41}$ \\ https://orcid.org/0000-0003-1347-4937 \\ Viktoria Babanina ${ }^{42}$ \\ https://orcid.org/0000-0003-4173-488X
}

\begin{abstract}
The article is devoted to the study of the peculiarities of combating fraud in the field of finance, in particular, combating crimes in the field of lending. The experience of Ukrainian law enforcement agencies in combating credit fraud has been studied. The experience of some European Union countries in combating financial fraud is analyzed. To achieve the goal of the paper a set of general scientific and special methods was used, such as method of system-structural analysis, dogmatic (formal-logical), historical, general sociological, comparative-legal method and others. It is concluded in the article that the rules of criminal law of Ukraine establish more severe penalties for some crimes compared to EU countries. For example, this applies to crimes in the field of money laundering. On the other hand, some offenses that do not qualify as crimes in Ukraine are recognized as criminal offenses in the EU. For example, this applies to abuses in the field of insurance. According to the results of the study, the solution of some important issues is proposed such as improvement of the current legislation in the field of credit and financial relations, adaptation of the legislation of Ukraine to international norms and standards in the system of credit and financial relations.
\end{abstract}

\section{Анотація}

Стаття присвячена дослідженню особливостей боротьби 3 шахрайством у сфері фінансів, зокрема, боротьби зі злочинами у сфері кредитування. Вивчено досвід українських правоохоронних органів у боротьбі 3 кредитними шахрайствами. Проаналізовано досвід деяких країн Європейського Союзу у боротьбі 3 фінансовими шахрайствами. Для досягнення мети статті було використано набір загальнонаукових та спеціальних методів, таких як метод системно-структурного аналізу, догматичний (формально-логічний), історичний, загальносоціологічний, порівняльно-правовий метод та інші. У статті зроблено висновок, що норми кримінального законодавства України встановлюють більш суворі покарання за деякі злочини порівняно 3 країнами ЄС. Наприклад, це стосується злочинів у сфері відмивання грошей. 3 іншого боку, деякі правопорушення, які не кваліфікуються як злочини в Україні, визнаються кримінальними злочинами в СС. Наприклад, це стосується зловживань у сфері страхування. За результатами дослідження пропонується вирішення деяких важливих питань, таких як вдосконалення чинного

\footnotetext{
${ }^{39}$ Rector of National Academy of Internal Affairs, Doctor of Law, Professor, Kyiv, Ukraine.

${ }^{40}$ Vice-Rector of National Academy of Internal Affairs, Doctor of Law, Professor, Kyiv, Ukraine.

41 Temporary Acting Head of Department of Criminal Law of National Academy of Internal Affairs, Doctor of Law, Professor, Kyiv, Ukraine.

42 Professor of Criminal Law Department of the National Academy of Internal Affairs, PhD in Law, Associate Professor, Kyiv, Ukraine.
} 
Key words: banking sector, financial fraud, insurance, insolvency, lending, money laundering. законодавства у сфері кредитно-фінансових відносин, адаптація законодавства України до міжнародних норм та стандартів у системі кредитно-фінансової відносини.

Ключові слова: банківський сектор,
фінансове неплатоспроможність, кредитування, відмивання коштів.

criminal activity in the field of lending undermines the stability of the economy and hinders the development of the country as a whole. Therefore, one of the priority activities of law enforcement agencies of Ukraine is the prevention of such crimes. Effective judicial protection of the rights and legally protected interests of participants in credit relations is an extremely important factor in maintaining the stability of the country's economy.

The purpose of the article is to study the principles of legal regulation and combating fraud in the field of lending, comparing approaches to combating financial fraud in Ukraine and some other European countries.

\section{Theoretical framework}

In the world, the problems of financial fraud are the focus of government (especially financial) bodies, international companies (including auditors, which annually conduct in-depth research on this phenomenon), scientists and the public. The research of various aspects of economic crime, including in the field of finance and credit activity, is devoted to the scientific works of many authors: L. Marriot (2019)., I. Sereda, M. Kostyuchenko (2020)., D.A. Hyman (2001)., E.H. Sutherland (1945)., P. Van der Nat $\&$ W. Keep (2002) and others.

Among mentioned, we would like to highlight the work of L. Marriot, who investigated whitecollar crimes in New Zeland. Her article suggests interesting decisions. Thus, in her opinion, the absence of restitution should be considered an aggravating factor, not the presence of restitution, which is considered a mitigating factor. Since the benevolent nature of the offender often contributes to the crime, this should not be considered a mitigating factor, and extraordinary punishments, such as deterioration of reputation or loss of future employment opportunities, are short-lived for criminals, punishment is unjustified, and extracurricular consequence of the offender (Marriot, 2019). 


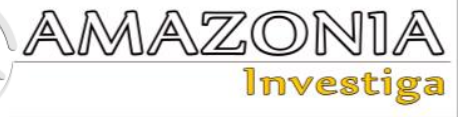

A very important conclusion concerning credit fraud we can find in the article of I. Sereda and M. Kostyuchenko. The scholars mention that the decrease in the number of registered credit frauds is influenced by the fact that more and more often banks refuse almost all types of retail loan applications. The main reasons for refusals are the credit history of consumers and their debt burden. Another common ground for refusal is a discrepancy between the information provided by the applicant and the information held by the creditor. In a systemic connection with the wellknown negative phenomena that accompany social development, these circumsta-nces have a strong criminogenic potential (Sereda \& Kostyuchenko, 2020).

Instead, in Ukraine, the problem of financial fraud is given insufficient attention by both members of the scientific community and civil servants who care about the development of the domestic financial sector. Moreover, Ukrainian scholars who study this issue consider financial fraud primarily through the prism of legal regulation, omitting the importance of its financial and economic component.

In Ukraine, the study of financial fraud is mainly in the field of view of representatives of legal science: A. Yermoshenko (2009), D. Kamensky (2013)., S. Knyazev (2011), O. Kurman (2008)., T. Mudryak (2015)., G. Chernyshov (2014)., S. Chernyavsky (2012)., S. Shapochka (2013), and others.

Thus, A. Yermoshenko in his article considers the place of insurance fraud in generating threats to the interaction of the insurance sector and the banking sector, provides comparable regimes to combat insurance fraud in different countries and in Ukraine at the legislative level (Yermoshenko, 2009).

S. Knyazev in his study analyzes the essence of financial pyramids as types of fraudulent schemes. He concludes that the financial pyramid is a technology of criminal activity, which is used as a way to seize someone else's property by deception and abuse of trust (fraud) under the guise of an investment project, membership in which is acquired subject to certain payments, contributions or other payments (Knyazev, 2011).

S. Shapochka studies and analyzes general theoretical works of specialists in the field of criminal law, criminology and criminal executive law related to the study of determinants of property crime, as well as information and statistics in the field of global Internet and telecommunications devices. He analyzes the prevention of computer fraud, cybersecurity, and provides suggestions for eliminating the conditions for cyber fraud and ways to effectively combat computer and telecommunications fraud (Shapochka, 2013).

Taking into account the current state of investigations in the field of financial fraud, the most important thing to emphasize in this research is a problem that financial fraud in Ukraine is mainly being investigated in the field of view of legal scholars, but Ukrainian economics (financial in particular), unfortunately, practically does not investigate these issues. Thus, from the list of thesis defended in Ukraine during 1998-2018 and devoted directly to the problems of financial fraud, there is no researches in the field of economic sciences. Paradoxically, despite the enormous negative socio-economic consequences of this phenomenon in modern life, no textbook on financial law for economics students touches on the topic of financial fraud at all.

\section{Methodology}

To achieve the goal of the study, a set of general scientific and special methods was used, which provided a thorough and comprehensive consideration of the issues that exist in the field of financial fraud.

Among the general scientific methods the author used: the method of system-structural analysis, dogmatic (formal-logical), historical, general sociological, comparative-legal and others. Among the special-scientific, in particular, methods of legal statistics and legal logic were used.

Using the method of structural and system analysis it was possible to study the structure of the system of criminal law, which provides for liability for crimes in the field of lending in Ukraine, the relationship and interdependence of elements within the system and with other criminal and financial concepts, their scope and content. The dogmatic (formal-logical) method allowed to analyze the norms of the current Criminal Code of Ukraine, which provide for liability for crimes in the field of lending. The historical method allowed to show the genesis of the problem of criminal law protection of lending in Ukraine, based on the analysis of criminal law of previous years and the practice of its 
application to identify trends in criminal law of Ukraine on liability for crimes in credit.

The method of comparative analysis has been widely used to study the world experience of preventing and combating financial fraud, identifying common and distinctive features in approaches to combating financial fraud in Ukraine and the EU. The general sociological method was used during the study of the practice of application of the norms of the Criminal Code of Ukraine, which establish liability for criminal encroachments in the field of lending. The analysis of the state and development of the economy, budget and tax systems, the activities of law enforcement agencies to identify and prevent these criminal offenses helped to identify shortcomings and gaps in the criminal law protection of lending in Ukraine. Methods of legal logic were used in the formulation of the current system of criminal law in the field of lending in Ukraine, based on the results of established factors of social conditionality of criminalization of socially dangerous acts.

The method of scientific generalization was used to substantiate the principles of combating financial fraud and to determine the scientific and methodological basis for the formation of state policy in the field of prevention and minimization of financial fraud. The method of analysis and synthesis was used to identify types of financial fraud and to identify fraud in the field of lending. The method of structuring and grouping was used to systematize the causes of financial fraud, to identify criteria and ways to combat fraud in the field of lending in law enforcement.

During the evaluation of the methods of implementation of fraudulent schemes in the field of lending, the methods of induction and deduction, the method of structural-functional comparison were used. The method of economic modeling was used in the formation of the model of implementation of state policy in the field of prevention and minimization of fraud in the field of lending. The main conclusions are formulated on the basis of methods of system analysis and scientific abstraction.

\section{Results and discussion}

\section{Countering crimes in the field of lending in the activities of law enforcement agencies of Ukraine.}

Combating crimes in the field of lending is an urgent problem of law enforcement in Ukraine, due to several factors.

First, the manifestations of fraud in the credit sector not only cause damage to creditors, but also negatively affect the stability of the entire financial system.

Secondly, these crimes have a high latency, as not all heads of financial institutions apply to law enforcement agencies with relevant statements (fearing for the business reputation of their organizations). In most cases, despite the significant damage caused, banking institutions do not properly organize claims work, but are limited to filing applications with law enforcement agencies, which complicates the evidence in the initiated cases.

Third, criminals conceal their actions in every possible way, in particular, use the services of fictitious enterprises, disguise their true intentions with the help of sham legal agreements, as well as criminal consequences of "unsuccessful" business activities, use modern computer and office equipment forge accounting and other documents, take measures to launder funds obtained by criminal means (Chernyavsky, 2012).

Criminals in preparation for committing crimes with credit resources try to:

- $\quad$ to create in the credit institution the visibility of a legally operating participant in economic activity;

- to be a solid, promising person who has significant financial resources to fulfill the terms of the loan agreement, to create the appearance of a wide range of connections;

- demonstrate the availability of means to ensure loan repayment;

- show the availability of production capacity and other conditions for the implementation of the economic project (Hyman, 2001).

To achieve this goal, criminals usually resort to:

- inclusion in the documents on the creation of a legal entity of information that does not correspond to reality;

- use of documents belonging to legal or natural persons who no longer officially carry out their activities;

- use without the consent of the owners of other people's accounts;

- production of fictitious payment and other documents, etc. 


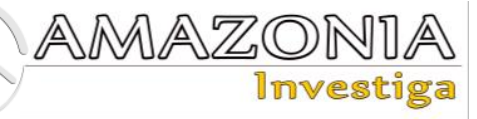

There are cases when criminals use stolen or purchased passports, forged documents, other people's names, etc. to obtain legal entity registration documents.

At present, there is a growing tendency for banks to initiate criminal proceedings against borrowers and guarantors in the event of noncompliance with credit obligations. The Criminal Procedure Code of Ukraine (Law No. 4651-VI, 2013) provides for an almost "automatic" procedure for instituting criminal proceedings. The creditor's statement on the basis of which the case is entered in the register is sufficient for this, and the investigating authorities are obliged to conduct an inspection. Completion of such an inspection for debtors depends on many factors, some of which are, in particular, the actual presence of signs of a crime in the debtor's actions, "lobbying" by the creditor to open a criminal case, the debtor's behavior in relations with the creditor, well-thought-out defense tactics (Chernyshov, 2014).

Significant interest from the creditor can be the basis for the development of the process of criminal prosecution, even those debtors whose actions do not show any signs of a crime, if, of course, do not consider such a partial default.

Among the most difficult situations the law enforcement agencies face with while combating crimes in the field of lending, is the distinction between fraud and financial resources (Article 222 of the Criminal Code of Ukraine) and crimes against property, in particular fraud under Art. 190 of the Criminal Code of Ukraine (Law No. 2341-III, 2001). The conclusion about the presence or absence at the time of the loan agreement of the borrower's intention to take possession of someone else's property free of charge (bank loan funds) must be made on a caseby-case basis, carefully examining all case materials.

The presence of signs of fraud in the actions of the borrower (Article 190 of the Criminal Code of Ukraine) (Law No. 2341-III, 2001) may indicate, in particular, the following circumstances:

1) sudden disappearance of the borrower from the place of residence for a period exceeding the loan repayment period provided for by the loan agreement (for individuals) or liquidation of the borrower enterprise without notifying the bank's representatives;

2) spending of credit funds not for the intended purpose, but for personal needs (using fictitious agreements, services of conversion centers, transfer of funds to foreign accounts, etc.);

3) signs of fictitiousness in the activities of the enterprise-borrower, in particular, the use of services of firms operating in violation of applicable law;

4) lack of real opportunities to fulfill credit obligations, awareness of managers and officials of the business entity about the insignificance, pretense of concluded agreements and directing this activity to illegal enrichment, impossibility of actual implementation of commitments taking into account the actual time, distance, location of counterparties from each other, the location of property or the amount of material resources economically necessary for the production of goods, works or services, failure of the organizer of the relevant activities;

5) use of forged documents, stamps, seals;

6) alienation of the collateral without the consent of the creditor;

7) the presence of signs of an organized criminal group, characterized by the duration of existence, the distribution of roles of accomplices, the hierarchy of the structure, etc. (Kryshevych, 2010).

Incorrect classification of crimes in criminal cases, as a rule, entails failure to take measures to compensate for damages.

The study of criminal cases showed that investigators, despite the presence of signs of crimes against property (Articles 190, 191 of the Criminal Code of Ukraine) or in the sphere of economic activity (Articles 222 of the Criminal Code of Ukraine), initiate cases under articles about other crimes (Articles 358, 366 Criminal Code of Ukraine) and further do not change qualifications (Law No. 2341-III, 2001).

Errors in the classification of crimes in the field of credit are associated primarily with an incorrect assessment of the facts of the perpetrator, i.e. a cursory examination and insufficiently complete clarification of the circumstances that are the subject of proof. Thus, despite the tendency to reduce applications and reports of crimes in the field of credit relations and, accordingly, criminal cases of crimes in this category, the issue of improving the effectiveness of criminal and criminal procedure law (Tikhonova, 2013).

The problem with the investigation of crimes in the field of credit in Ukraine is that the 
investigation is carried out by outdated methods, without taking into account changes in the methods and technologies of criminal activity. The emergence of new phenomena, such as websites (Nekit, Ulianova \& Kolodin, 2019), the Internet of Things (Nekit, Kolodin \& Fedorov, 2020), cryptocurrencies, can provoke the emergence of new types of crime, which will require new approaches to investigating and combating them (Shapochka, 2013).

\section{The experience of some European countries in the field of combating financial fraud.}

The problem of adaptation of the criminal legislation of Ukraine to the legislation of European countries in the field of prevention of crimes encroaching on credit relations has not been covered at the scientific level, but it is advisable to conduct such research in the near future. In this regard, it is necessary to compare the articles of the Criminal Codes of some European Union countries (Denmark, Germany, Austria, Poland, Spain, Switzerland) with the Criminal Code of Ukraine, according to which liability for crimes committed in the field of lending (Shulyak, 2013).

For example, it is advisable to consider crimes that encroach on public relations in terms of ensuring the interests of legal entities or individuals and the state related to insolvency. Thus, it should be noted that when committing such acts, damage may be caused in some cases to credit relations, and in others to certain types of economic relations. These crimes include, in particular, bankruptcy (Article 219 of the Criminal Code of Ukraine (Law No. 2341-III, 2001), Article 301 of the Penal Code of Poland (Law № 43864, 1997), Article 159 of the Criminal Code of Austria (Law № 60/1974, 1974), paragraphs 2, 8 (2) of Article 283 of the German Criminal Code (Law № 3322, 1998), Article 165 of the Swiss Criminal Code (Law № SR/RS 311, 1942), Article 260 of the Criminal Code of Spain (Law № 10/1995)). Analyzing the criminal law of European states, it should be noted that in contrast to the criminal law of Ukraine, there is a slightly different approach to understanding the criminal acts related to insolvency. Thus, the corpus delicti, provided by Art. 218-1 of the Criminal Code of Ukraine(Law No. 2341-III, 2001), is typical only for the criminal legislation of Spain. Under the laws of other European countries, such an act is not criminally punishable. Under Danish criminal law, all insolvency offenses are non-criminal and subject to administrative liability.
The next type of crimes that should be considered are crimes that encroach on public relations in the field of ensuring the legality of financing, lending, the implementation of certain activities in the field of lending. This group of crimes, the responsibility for which is enshrined in most of the Criminal Code of European countries, includes such dangerous encroachments as money laundering (Article 209, Criminal Code of Ukraine (Law No. 2341-III, 2001), Article 299 of the Criminal Code of Poland (Law № 43864, 1997), Article 165 of the Criminal Code of Austria (Law № 60/1974, 1974), Article 261 of the German Criminal Code (Law № 3322, 1998), Article 301 of the Criminal Code of Spain (Law № 10/1995), Article 305bis of the Swiss Criminal Code (Law № SR/RS 311)), fraud with financial resources (Article 222 of the Criminal Code of Ukraine (Law No. 2341-III, 2001), Article 297 of the Criminal Code of Poland (Law № 43864, 1997), Articles 152, $153 \mathrm{~b}$ of the Criminal Code of Austria (Law № 60/1974, 1974), Articles 264-1, 265 of the German Criminal Code (Law № 3322, 1998), Articles 308, 309 of the Criminal Code of Spain (Law № 10/1995), Article 305 ter of the Swiss Criminal Code (Law № SR/RS 311, 1942)).

Attention should be paid to the severity of punishment under the Criminal Code of Ukraine in the legalization (laundering) of funds obtained by criminal means. In this case, the upper limit of punishment is 15 years of imprisonment, although according to the criminal law of European countries this limit does not exceed 5 years of imprisonment (Poland, Austria), imprisonment (Switzerland), 6 years (Spain), 10 years (Germany).

The criminalization of acts related to fraud with financial resources has become a topical issue in European countries. In addition to the classical understanding of this crime (providing a business entity with knowingly false information to the authorities, credit and financial institutions in order to obtain loans, subventions, grants, etc.) in some criminal laws of Europe enshrined a number of rules establishing liability for various veiled forms of commission financial fraud. For example, fraud with falsification of the insured event (Article 298 of the Criminal Code of Poland (Law № 43864, 1997), Article 263 (5), 265 of the German Criminal Code (Law № $3322,1998)$, Article 151 of the Criminal Code of Austria (Law № 60/1974, 1974)), investment fraud (Article 264a of the German Criminal Code (Law № 3322, 1998)), chain games and financial pyramids (Article 168a of the Criminal Code of 


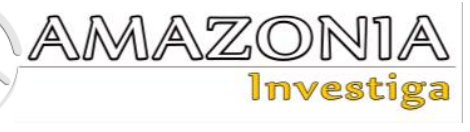

Austria (Law № 60/1974, 1974)), fraud with the use of prohibited checks, time obligations etc.

Such specification of criminal law is important for the correct qualification of a particular criminal act, especially in cases where there are complications in distinguishing a crime from a financial offense. Thus, in most countries of the European Union, in contrast to Ukraine, various types of insurance abuse have been recognized as criminal. Although the situation in Ukraine is particularly noteworthy in the field of insurance.

\section{Directions for improving the criminal legislation in the field of credit relations as a way to combat credit fraud.}

In Ukraine, special attention is paid to the development of the rule of law, legal institutions, improving their quality, improving legislation. The importance of the law in the prevention of crimes in the field of credit relations is extremely important.

With regard to solving the problem of crime prevention in the field of credit, a targeted system of legal measures is needed to ensure the reduction and complete neutralization of the causes and factors that contribute to the commission of such crimes at all stages and levels.

Credit and financial activity in Ukraine is regulated by numerous legislative acts, the main of which are the Laws of Ukraine: "On Banks and Banking" (Law No. 2121-III, 2000), "On Credit Unions" (Law No. 2908-III, 2001), "On Financial Services and State Regulation of Financial Services Markets" (Law No. 2664-III, 2001). The credit system has great potential for positive impact on economic development, and at the same time has a negative impact of unresolved legal provisions, shortcomings of credit and financial technologies, document flow, insufficient professional level of credit workers, as well as the possibility of abuse by credit and financial institutions. These circumstances exacerbate the criminogenic situation and contribute to the growth of criminal encroachments on credit and financial relations (Mudryak, 2015).

Scholars insist on the need to strengthen criminal liability for crimes committed in the field of banking. It may be worthwhile to include in the structure of the Criminal Code of Ukraine the article "Illegal obtaining of a bank loan" (Law No. 2341-III, 2001). Given the peculiarities of the criminal legislation of Ukraine, cases of illegal obtaining of loans in general in practice are qualified as "fraud" under Art. 190 of the Criminal Code of Ukraine (Law No. 2341-III, 2001). However, the subject of fraud can be both someone else's property and the right to such property, and when receiving a loan it is about money, not property (Klochko, 2014).

In Ukraine, there is a need to improve certain provisions of the special part of the Criminal Code of Ukraine, which provides for liability for crimes against credit and financial relations. After all, in the context of the growth of the shadow economy, the spread of organized crime, the acquisition of such crimes of an international nature, the appropriate systematization of criminal law is of great importance. Obviously, it is necessary to take full account of international experience, to carry out a number of scientific developments on the criminalization and decriminalization of certain abuses that encroach on the system of credit relations.

It should be noted that it is advisable to decriminalize (full or partial) the corpus delicti, the responsibility for which is provided by Art. 218-1 of the Criminal Code of Ukraine (bringing the bank to bankruptcy) and Art. 220 of the Criminal Code of Ukraine (Law No. 2341-III, 2001) (concealment of persistent financial insolvency) with their transfer to administrative responsibility, as the fictitious financial condition of any business unit can be clarified and challenged during the bankruptcy proceedings in commercial courts (Pivovarov, 2003).

It should be noted that when deciding on the transfer of these acts in the framework of administrative liability, it is necessary to set the appropriate lower limit of the amount of the fine. The point is that penalties should be significant, as these acts usually cause great material damage (Avci, Schipani \& Seyhun, 2018).

Legislation in the field of credit relations, which needs to be improved, is reflected in other areas of law and legislation. These include some of the rules of criminal procedure law, administrative, financial and other branches of law. Thus, in criminal procedure law there are rules that directly indicate the identification of causes and conditions that contribute to the commission of crimes, as well as the obligation of the inquiry, investigation and prosecutor's office to submit measures to eliminate these causes and conditions (Kurman, 2008). 
Norms of administrative law regulate the management of law enforcement agencies that prevent crimes in the field of credit relations, consolidate the administrative influence on those released from punishment, provide other measures related to the prevention of crimes in this area.

Norms of financial law regulate relations in the field of banks and other credit institutions, determine the procedure for financial control (verification of financial obligations to the state and all subjects of the credit and financial system; verification of compliance with financial rules, settlements and savings these institutions, prevention and elimination of identified violations of financial discipline, etc.), establish liability for failure to comply with instructions.

Thus, legal measures to prevent crimes in the field of credit relations constitute a system of measures that relate to various areas of law and legislation.

The above mentioned indicate that there is a need to increase guarantees to address the prevention of crimes in the field of credit. First of all, it is necessary to accurately and objectively determine the range of entities that will carry out crime prevention in this area, their competence, increase responsibility and interaction. The issue of creating a unified system of legal norms in solving this problem is relevant.

In order to reduce the crime rate, it is first of all necessary to reform and improve the criminal legislation and the legislation on crime prevention. The next step should be to reform the legislation in the field of credit relations. It should be noted that such atrocities should apply only to financial sanctions for crimes committed, as the vast majority of such crimes cause great material damage.

Given the importance of legal measures to prevent crimes in the field of credit, it is necessary not to exaggerate their potential, as it goes beyond legal regulation. At the same time, one should not ignore the fact that legal measures should not eliminate punishment. Therefore, they should be joined by other measures, including measures of organizational and managerial nature (Khamyha, 2020).

We consider it expedient to supplement the current Criminal Code of Ukraine with independent corpus delicti of crimes "Credit fraud", "Illegal obtaining of credit", "Malicious evasion of repayment of accounts payable".
However, in the legislative implementation of the crime "Malicious evasion of repayment of accounts payable" the provisions of Art. 1 of Protocol No. 4 to the European Convention for the Protection of Human Rights and Fundamental Freedoms (Council of Europe, 1950) should be considered. According to these provisions, "no one shall be deprived of his liberty merely because he is unable to fulfill his contractual obligation". In view of the above, it is necessary to provide for such a crime only "alternative" types of punishment, i.e. those that are not related to arrest and imprisonment.

Thus, the whole set of legal norms that are directly or indirectly aimed at better regulation of credit and financial relations and the system of legislative support of law enforcement agencies for the protection of rights refers to legal measures to prevent crimes in the field of credit relations.

\section{Conclusions}

1. Crimes committed in the field of credit relations are one of the most dangerous financial and economic crimes, as their negative impact spreads and is reflected not only on the credit and financial system of Ukraine, but also on other important objects of economic activity. In most cases, socially dangerous acts in the field of lending are classified under Art. 190 of the Criminal Code of Ukraine "Fraud" and Art. 222 of the Criminal Code of Ukraine "Fraud with financial resources" (Law No. 2341III, 2001).

According to court practice, often the qualification of these crimes is carried out in conjunction with te crimes under Articles 357, 358,366 of the Criminal Code of Ukraine (Law No. 2341-III, 2001) . Thus, in order to illegally obtain a loan, theft or illegal purchase of passports, forgery of documents, use of other people's names, etc. are committed.

The analysis of court practice shows the frequent "variability" of positions in the decisions of higher specialized courts on the same issues related to liability, including criminal, in the field of lending. It should be acknowledged that these courts are insufficient work, both on the interpretation of legal norms that protect the field of credit, and on the generalization of the practice of lower courts in this category of disputes.

2. The main reason for the rapid growth of crime in the field of lending, as well as errors 


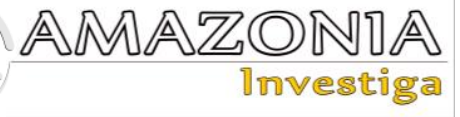

in the legal classification of criminal acts, is the imperfection of both criminal law of Ukraine and lending legislation. Thus, the obvious inconsistency of the national legal framework with the requirements of the European Union has already led to the inclusion of Ukraine in the lists of countries that are not properly able to cooperate in the prevention of credit crimes.

3. It is important to improve the legislation on crime prevention in the field of lending, which would be aimed at better regulation of credit and financial relations, protection of the rights and economic freedoms of all parties, as well as the system of regulatory support of law enforcement agencies. This legislation should be based, first of all, on the principle of the rule of law, as well as equality in the opportunities of the subjects of credit relations. The scientific elite and the legislature should focus more on criminal liability for creating financial pyramids and "complicated forms" of financial fraud.

4. We consider it expedient to single out an independent section "Crimes in the credit and financial system" in the current Criminal Code of Ukraine. It is also expedient to supplement the current Criminal Code of Ukraine with independent corpus delicti of crimes "Credit fraud", "Illegal obtaining of credit", "Malicious evasion of repayment of accounts payable".

However, in the legislative implementation of the crime "Malicious evasion of repayment of accounts payable" the provisions of Art. 1 of Protocol No. 4 to the European Convention for the Protection of Human Rights and Fundamental Freedoms should be considered, and therefore only "alternative" types of punishment, i.e. those not related to arrest and imprisonment should be provided.

\section{References}

Avci, S., Schipani, C. \& Seyhun, H. (2018). Do independent directors curb financial fraud? The evidence and proposals for further reform. Indiana Law Journal, 93(3), 757-805.

Chernyavsky, S. (2012). Solving the problems of combating fraud with financial resources in the banking sector. Legal Journal of the National Academy of Internal Affairs, 1(3), 84-93. Retreived from http://irbis-nbuv.gov.ua/cgibin/irbis_nbuv/cgiirbis_64.exe?I21DBN=LINK $\& \mathrm{P} 21 \mathrm{DBN}=\mathrm{UJRN} \& Z 21 \mathrm{ID}=\& \mathrm{~S} 21 \mathrm{REF}=10 \& \mathrm{~S} 2$ $1 \mathrm{CNR}=20 \& \mathrm{~S} 21 \mathrm{STN}=1 \& \mathrm{~S} 21 \mathrm{FMT}=\mathrm{ASP} \_$meta $\&$
C21COM=S\&2_S21P03=FILA=\&2_S21STR=a ymvs_2012_1\%283\%29_12

Chernyshov, G. (2014). Criminological characteristics of fraud in the investment and construction sector. Scientific Bulletin of the International Humanities University. Series: Jurisprudence, 10-1, 98-101.

Council of Europe. (1950). Convention for the Protection of Human Rights and Fundamental Freedoms. Retrieved from https://www.echr.coe.int/documents/convention _eng.pdf

Hazel, C. (1994). White collar crime: criminal justice and criminology. Buckingham Philadelphia, $127 \mathrm{p}$.

Hyman, D. (2001). Health care fraud and abuse: market change, social norms and the trust reposed in the workmen. The Journal of Legal Studies, 30(2), 531-567. Retrieved from https://www.jstor.org/stable/10.1086/324674

Kamensky, D. (2013). Financial fraud in the United States: some issues of criminal responsibility. Law Forum, 1, 379-385.

Khamyha, Yu. (2020). Financial pyramids as a type of financial fraud: theoretical-motivational aspect. European Journal of Economics and Management, 6(3), 15-22.

Klochko, A. (2014). Crimes in the field of banking. Legal Bulletin of the Ukrainian Academy of Banking, 1, 68-71.

Knyazev S. (2011). Financial pyramid as a way of fraud in the market financial services. Law and management, 1, 204-211.

Kryshevych, O. (2010). Fraud: a comparative analysis of criminal legislation of Ukraine and international criminal law. Legal Bulletin. Air and space law, 2, 76-79.

Kurman, O. (2008). Features of information detection and verification regarding fraud with financial resources. Entrepreneurship, economy and law, 4, 123-125.

Law No. 2121-III. On Banks and Banking. Bulletin of Verkhovna Rada of Ukraine, Kyiv, Ukraine, 2000.

Law No. 2341-III. Criminal Code of Ukraine. Bulletin of Verkhovna Rada of Ukraine, Kyiv, Ukraine, April 5, 2001.

Law No. 2664-III. On financial services and state regulation of financial services markets. Bulletin of Verkhovna Rada of Ukraine, Kyiv, Ukraine, 2001.

Law No. 2908-III. On credit unions. Bulletin of Verkhovna Rada of Ukraine, Kyiv, Ukraine, 2001.

Law No. 4651-VI. Criminal Procedure Code of Ukraine. Bulletin of Verkhovna Rada of Ukraine, Kyiv, Ukraine, April 14, 2013. 
Law № 10/1995. Criminal Code of Spain. Official State Gazette, Madrid, Spain, November 23, 1995.

Law № 3322, 1998. German Criminal Code.Federal Law Gazette I, Berlin, Germany, November 13, 1998

Law № 43864, 1997. Penal Code of Poland. Dziennik Ustaw, Warsaw, Poland, June 6, 1997. Law № 60/1974. Criminal Code of Austria. Wiener Zeitung, Wien, Austria, January 23, 1974.

Law № SR/RS 311. Swiss Criminal Code. Swiss Official Gazette, Berne, Switzerland, January 1, 1942.

Marriot, L. (2019). White-collar crime: the privileging of serious financial fraud in New Zealand. Social and legal studies, 29(4), 486506. DOI: $10.1177 / 0964663919883367$

Mudryak, T. (2015). Regulatory and legal support of fraud investigation with financial resources. International Legal Bulletin: a collection of scientific papers of the National University of the State Tax Service of Ukraine, 1, 121-126.

Nekit, K., Kolodin D. \& Fedorov, V. (2020). Personal data protection and liability for damage in the field of the Internet of Things. Juridical Tribune, 10(1), 80-93. Retrieved from http://tribunajuridica.eu/arhiva/An10v1/5.\%20N ekit,\%20Kolodin,\%20Fedorov.pdf

Nekit, K., Ulianova, G. \& Kolodin, D. (2019). Website as an object of legal protection by Ukrainian legislation. Amazonia investiga,
$8(21)$ 222-230. https://amazoniainvestiga.info/index.php/amazo nia/article/view/97

Pivovarov, V. (2003). Definition and ways of criminological study of financial crime. Law of Ukraine, 1, 107-111.

Sereda, I. \& Kostyuchenko, M. (2020). Criminological indicators of credit fraud. Russian journal of criminology, 14(3), 441-452. DOI: 10.17150/2500-4255.2020.14(3).441-452 Shapochka, S. (2013). Preventing fraud using computer networks. Internal Security, 2, 63-75. Shulyak, Yu. (2013). Use of international experience to improve criminal liability for fraud. Scientific Bulletin of the National Academy of Internal Affairs, 3, 345-351.

Sutherland, E. H. (1945). Is «White Collar Crime» Crime? American Sociological Review, 10, 132-139.

Tikhonova, O. (2013). Some features of crime in financial credit sphere in today's conditions. Public law, 4, 105-113.

Van der Nat, P. \& Keep, W. (2002). Marketing Fraud: An Approach for Differentiating Multilevel Marketing from Pyramid Schemes. Journal of Public Policy and Marketing, 21(1), 139-151.

Yermoshenko, A. (2009). Insurance fraud as a source of threats in the interaction of insurers and banks. Retrieved from https://essuir.sumdu.edu.ua/bitstreamdownload/123456789/54055/5/Yermoshenko_in surance_fraud1.pdf 